\title{
Antiquity, botany, origin and domestication of Jatropha curcas (Euphorbiaceae), a plant species with potential for biodiesel production
}

\author{
L.A.S. Dias ${ }^{1}$, R.F. Missio ${ }^{2}$ and D.C.F.S. Dias ${ }^{3}$ \\ ${ }^{1}$ Departamento de Fitotecnia, Universidade Federal de Viçosa, Viçosa, \\ MG, Brasil \\ ${ }^{2}$ Universidade Federal do Paraná, Campus Palotina, Palotina, PR, Brasil \\ ${ }^{3}$ Departamento de Fitotecnia, Universidade Federal de Viçosa, Viçosa, \\ MG, Brasil
}

Corresponding author: L.A.S. Dias

E-mail: lasdias@ufv.br

Genet. Mol. Res. 11 (3): 2719-2728 (2012)

Received March 14, 2012

Accepted June 5, 2012

Published June 25, 2012

DOI http://dx.doi.org/10.4238/2012.June.25.6

\begin{abstract}
Jatropha curcas is a multi-purpose plant species, with many advantages for biodiesel production. Its potential oil productivity is $1.9 \mathrm{t} /$ ha, beginning the fourth year after planting. Nevertheless, limitations such as high harvest cost, lack of scientific konowledge and low profitability have prevented it from being utilized commercially. In order to provide information that could be useful to improve the status of this species as a bioenergy plant, we elucidated the center of origin and the center of domestication of $J$. curcas (Mexico). Evidence of the antiquity of knowledge of $J$. curcas by Olmeca people, who lived 3500-5000 years ago, reinforces its Mexican origin. The existence of non-toxic types, which only exist in that country, along with DNA studies, also strongly suggest that Mexico is the domestication center of this species. In Brazil, the Northern region of Minas Gerais State presents types with the highest oil content. Here we propose this region as a secondary center of diversity of $J$. curcas.
\end{abstract}

Key words: Center of origin; Center of domestication; Biodiesel; Secondary center of diversity; Physic nut 


\section{INTRODUCTION}

Jatropha curcas is a multi-purpose species. Extracts from its leaves, bark, roots, seeds, and latex present different and important medicinal properties for animals and humans. J. curcas seeds contain, on average, $38 \%$ oil, with exceptional characteristics for the production of biodiesel. The plant as a whole presents favorable attributes for use as living fences and for recovering degraded areas. It is a perennial shrub with an estimated productive life cycle of up to 40 years. Its yield potential is $5 \mathrm{t} / \mathrm{ha}$ of grains, corresponding to $1.9 \mathrm{t} / \mathrm{ha}$ of oil, and its productive climax starts from the 4th year after planting. These competitive advantages make $J$. curcas a promising oil plant for commercial cultivation, especially for household agriculture. Researches have been carried out to understand and develop the commercial cultivation of $J$. curcas (Foidl et al., 1996; Heller, 1996; Openshaw, 2000; Dias et al., 2007; Jongschaap et al., 2007; Achten et al., 2008; Dias, 2011).

Scientists from several specialties and large corporations from the energy sector promote $J$. curcas as one of the most promising oil plant species for biodiesel production. Governments and their incentive agencies have made a growing volume of resources available for research, and large corporations have invested a great deal in its wide scale planting. China and India, for example, already have 2.6 million hectares planted with $J$. curcas (Fairless, 2007). In Latin America, there is significantly less enthusiasm for J. curcas. In fact, the planted area is only 21.8 thousand hectares, 15 thousand of which are in Brazil, with the remainder distributed among Mexico, Colombia, and Guatemala (Gexsi, 2008). These modest data for Latin America, in particular for Brazil, may even be overestimated, as there are many interests at play. Associations and refineries that defend J. curcas cultivation tend to tout a scenario much greater than reality, with the objective of creating an enthusiastic portrait of large scale planting which, in truth, to date, does not exist.

Other aspects that reinforce the suspicion of the overestimate of planting in Brazil are the high costs of implementation, maintenance, and harvest of $J$. curcas cultivation and the low remuneration offered to household farmers by refineries. According to Dias et al. (2007), for these farmers, the average implementation cost per hectare is around US\$1200, and the return from this investment only begins from the 4th year of planting. Furthermore, J. curcas demands intense mineral nutrition (Laviola and Dias, 2008), it bears fruit that does not uniformly mature, and it has a high incidence of pests and diseases (Dias et al., 2007). Fertilizing, harvest, and the control of pests and diseases account for up to $80 \%$ of the production costs. In contrast to these high costs, the average remuneration of a ton of J. curcas grains, with $11 \%$ moisture, is US\$160. The market price per ton of $J$. curcas crude oil, with $98.5 \%$ purity, is about US\$360, assuming an average yield of $38 \%$ oil in the grains. This is about the same as the value per ton of soybean crude oil, with $99.9 \%$ purity.

If on the one hand refineries do not currently remunerate well, on the other hand, they offer an innovative attraction to Brazilian agribusiness in the form of contracts to purchase $J$. curcas grains in the long term, some of them up to 5 years. It is a question of a fidelity mechanism and a promise between suppliers and industry, very welcome to the agro industrial sector. Considering the low remuneration of the oil at present, the unanswered question that remains, and which constitutes a real worry of the producers, is how much the market will pay when there is an abundant supply of $J$. curcas oil.

In this scenario, the cultivation of $J$. curcas is only viable as a 3 rd or 4 th income 
planting for producers who explore 2 or 3 other profitable agribusinesses, such as coffee and eucalyptus crops and cut cattle raising, among others. The implementation of an agricultural credit policy would certainly help viability. Agricultural credit, though a necessary condition, nevertheless, is insufficient. Adopting credit will not help the producers at all if they do not receive income from their investments. Those receiving credit need to be able to make payments and still guarantee sustainability. It is also necessary to make intercropping systems with $J$. curcas with annual food crops such as peanut or common bean, in order to secure income for the farmer during the early period of the plant, which corresponds to the first 4 post-planting years.

There are other types of promising intercropping, as discussed by Dias et al. (2008). One of these is called energetic density, when 2 or more oil crops are planted in the same area, as with the example of $J$. curcas with the macaw palm (Acrocomia aculeata) or J. curcas with annual oil plants such as crambe (Crambe abyssinica) or safflower (Carthamus tinctorius). The predicted oil productivity per area can reach, $5 \mathrm{t} / \mathrm{ha}$ in the case of $J$. curcas/macaw intercropping, producing $2 \mathrm{t} / \mathrm{ha}$ from $J$. curcas and $3 \mathrm{t} / \mathrm{ha}$ from macaw. Another promising intercropping is cattle-raising-oil integration, where $J$. curcas is planted, or macaw, or both, in areas of pasture. In this situation, besides the products derived from raising dairy or cut cattle (milk, meat, and leather), vegetable oil, and tallow are obtained for biodiesel. All of these types of intercropping can eventually be carried out with commitment. The evaluation and economic viability of these arrangements, however, still need to be defined through research.

In summary, despite global enthusiasm for $J$. curcas, it is necessary to be aware that this plant is not ready for wide cultivation. In Brazil, J. curcas still does not rely on improved cultivars, certified seeds, climatic-soil zoning, a definite production system, or commercial scale production. Thus, there are still serious risks in the decision to plant extensive areas because of existent unimproved genotypes and because of the level of technology currently available for $J$. curcas cultivation. These risks are even greater for household farmers, who are often induced to cultivate $J$. curcas in local production arrangements. It is important to note that household agriculture is vulnerable to risk and presents a low capacity for failure resistance. It is also important to remember the failure of the Austrian-Nicaraguan project of planting $J$. curcas on a wide scale in the 1990s in Nicaragua, installed using 'Cape Verde" and 'Nicaragua' cultivars. The project involved the planting of 1013 hectares by householder and a refinery with capacity of 8 thousand tons of biodiesel per year, and after three years of harvest, it was determined to be economically unviable (Nogueira, 2004). It was abandoned due to cooperation problems involving farmers, but especially due to the lack of productivity of the plantations, after consuming 3 million dollars. For household farmers without capital and infrastructure, the best thing to do may be to wait for research support, as future results should substantially reduce cultivation risks. The current reality does not abort the potential social benefits, high social inclusion capacity, and possibility of partial substitution of diesel with biodiesel that $J$. curcas cultivation represents. $J$. curcas is a promise that, if treated with responsibility, could possible become an economic reality.

\section{ANTIQUITY}

Due to its exceptional medicinal properties, it is reasonable to suppose that $J$. curcas has been a plant species known to humanity since antiquity. Medicinal plants have accom- 
panied man since ancient times. In fact, the use of medicinal plants by native cultures has shaped traditional medicine. Nevertheless, ethnobotanic studies can rarely prove the antiquity of the medicinal use of plants because of the historical limitations of oral traditions. In most cases, traditional medicine is passed on orally, generation after generation. Thus, for cultures that do not present written records and/or archaeobotanical evidence, it is practically impossible to prove antiquity uses of $J$. curcas.

Nevertheless, Leonti et al. (2003), after comparing the pharmacopeias of 2 linguistically related people, in this case Lowland Mixe and Zoque-Popoluca, proved the use of medicinal plants from antiquity. These two native peoples still live today in the Olmeca region of Mexico. It is important to emphasize that the Olmecas were the first people to colonize Mesoamerica, from approximately 1500-3000 years BCE, and they influenced many subsequent cultures, including the Mayas and Aztecs. The Lowland Mixe and Zoque-Popoluca populations, living in the Mexican states of Oaxaca and Veracruz, respectively, remained isolated for approximately 2000 years. In spite of this long period of isolation, these cultures present common vernacular cognates for medicinal plant names. Leonti et al. (2003) detected cognate names for 15 plant species and common use for 62 plant species, among them $J$. curcas, which was used to treat skin diseases, demonstrating a transfer of knowledge and common selection criteria for medicinal plants between these two peoples.

It is important to bear in mind, as argued by Haude (1998), that prior to the arrival of the Spanish, indigenous Mexican cultures enjoyed a rich technological history. Among other achievements, these various cultures made paper, books, and pigments; painted murals, ceramics, and manuscripts; erected elaborate sculptures and architecture; cultivated crops and botanical gardens; and engaged in medical practices. In addition, written languages culminated in a strong tradition of written and pictorial texts, or codices. Particularly adept at creating pictorial manuscripts were the Mixtecs of southern Mexico, the central Aztecs of Mexico, and the Maya of the Yucatán peninsula. Under the auspices of the priesthood, preconquest manuscripts and codices were produced by professional scribes from the Native elite.

Another evidence of the antiquity of $J$. curcas has been supplied by Haude (1998). While analyzing the use of colorings in maps passed down from the Olmecas, the author discovered that the Aztecs, influenced by the Olmecas, mixed pigments with the oil of Coccus axin (Emmart, 1961), an insect found in J. curcas trunks (Standley, 1967). Purple coloring, presumably obtained from $J$. curcas seeds, and known as cuauhy-ohuachtli, has been used by the Aztecs (Wallert, 1997). All these findings related to the transmission of knowledge between generations are strong evidences that the Olmecas, the population that preceded the Mayas and Aztecs who lived 3500 to 5000 years ago, knew and cultivated J. curcas.

\section{BOTANY}

The Euphorbiaceae family, composed of more than 8000 species, contains distinct representatives in commercial exploitation, such as the Hevea brasiliensis (rubber tree), Manihot esculenta (manioc), and Ricinus communis (castor oil). J. curcas, pertaining to the Joannesia tribe, is also one of these. The Jatropha genus is composed of 170 species and 2 subtypes: Jatropha (monophyletic) and Curcas (paraphyletic), both with 10 sections and 10 subsections to accommodate species from the new and old world. These subtypes were distinguished by 
characteristics relative to growth habit, bud, corolla, plant sexuality, number, and arrangement of stamens, the seed shape, and the presence or absence of caruncle. J. curcas, inserted in the Curcas section, is supposedly the most primitive form (McVaugh, 1945; Wilbur, 1954; Dehgan and Schutzman, 1994). It is an allogamous diploid species with 22 small chromosomes (Dahmer et al., 2009).

$J$. curcas is a shrub-tree that can reach a height of $5 \mathrm{~m}$ during cultivation, formed by juicy multi-branched stem. The plant is monoecious, with the inflorescences in chapters appearing at the extremities of the branches, a characteristic that shows the importance of winter pruning the cultivation. Besides promoting rejuvenation, pruning significantly increases the number of branches and, consequently, the number of inflorescences. The inflorescences appear in the beginning of the rainy season and produce unisexual male and female flowers and, occasionally, hermaphrodite flowers. There are 3 or 4 flows of blooming during this period (Foidl et al., 1996; Heller, 1996; Dias et al., 2007).

The fruits, containing an average of 3 seeds, ripen non-uniformly in approximately 60 days, and they acquire a yellow and dark brown color at harvest time. The root system is formed by up to 4 lateral roots and a taproot, which can reach $5 \mathrm{~m}$ in depth (Foidl et al., 1996; Heller, 1996; Dias et al., 2007). The plant demands nutrients in large quantities, especially nitrogen and potassium (Laviola and Dias, 2008) and is found from sea level up to $3000 \mathrm{~m}$ altitude, in variable rainfall from 250 to $2500 \mathrm{~mm}$ per year. Meanwhile, under commercial cultivation for high productive performance of grains, as Dias et al. (2007) argue, the plant requires average temperatures between $18^{\circ}$ and $28^{\circ} \mathrm{C}$, average annual rainfall above $600 \mathrm{~mm}$, and an altitude between 200 to $800 \mathrm{~m}$. $J$. curcas is deciduous, a mechanism that limits water loss and minimizes the effect drought, which is manifest by the abscission of the leaves. Being deciduous is an important evolutionary mechanism, because it increases the possibility of survival and production under times of severe drought, which are typical of arid and semi-arid regions. The deciduous period takes place during the winter and signals pruning time, when the metabolic activity of the plant declines significantly.

The list of products obtained from J. curcas is large (Table 1) and proves its multi-use plant species characteristic. However, it should be remembered that $J$. curcas seeds contain toxic compounds, and for this reason they cannot be consumed for nutritional purposes by humans and animals, either in the form of oil or press cake, which are both obtained from roasting and pressing the seeds. The seeds contain a toxin called curcin. In addition to curcin, toxic compounds, including phorbol esters (a family of compounds known to cause a large number of biological effects such as tumor promotion and inflammation), saponins, phytates, and trypsin inhibiters have been isolated from alcoholic extracts of $J$. curcas oil (Makkar et al., 1997). However, J. curcas press cake, is rich in macronutrients, containing 3 to $4.5 \% \mathrm{~N}$, 0.65 to $1.2 \% \mathrm{P}_{2} \mathrm{O}_{5}, 0.8$ to $1.4 \% \mathrm{~K}_{2} \mathrm{O}$, and 0.2 to $0.5 \% \mathrm{~S}$, along with micronutrients in quantities of $800-1000,300-500,30-50$, and $18-25 \mathrm{mg} / \mathrm{kg} \mathrm{Fe}, \mathrm{Mn}, \mathrm{Zn}$, and $\mathrm{Cu}$, respectively (Ghosh et al., 2007). In trials with $J$. curcas fertilized with $J$. curcas press cake, an increase from 93 to $120 \%$ in grain yield occurred, in densities of 833 and 1667 plants, respectively, when the press cake was applied in the quantity of $3 \mathrm{t} / \mathrm{ha}$ (Ghosh et al., 2007). When it is detoxified, it can be applied as a supplement to animal food, because it consists of 56\% protein (CETEC, 1983). J. curcas oil presents exceptional fuel characteristics and has been recommended for biodiesel production in an even 50\% mixture with petro diesel, without need to change diesel engines (Pramanik, 2003). 
Table 1. Some traditional and nontraditional uses and respective sources derived from Jatropha curcas.

\begin{tabular}{lll}
\hline Uses & Sources & References \\
\hline Bioethanol & Press cake & Visser et al., 2011 \\
Living fence & Living plants & Zahawi, 2005 \\
Degraded area & Living plants & Zahawi, 2005 \\
Medicinal properties & Extracts from seeds, fruits, leaves, and roots & Coe, 2008 \\
Oil for biofuel & Seeds & Foidl et al., 1996; Gübitz et al., 1999; Achten et al., 2008 \\
Oil for lamps (burns without soot) & Seeds & CETEC, 1983 \\
Press cake for fertilizer & Seeds & CETEC, 1983; Foidl et al., 1996; Gübitz et al., 1999 \\
Coach & Fruit husk & CETEC, 1983; Foidl et al., 1996 \\
Soap & Seeds & CETEC, 1983; Foidl et al., 1996; Gübitz et al., 1999 \\
Molluscidal property & Press cake & Rug et al., 1997 \\
Insecticidal property & Seed oil & Adebowale and Adedire, 2006 \\
Fungicidal property & Fresh leaves extracts & Sharma and Trivedi, 2002 \\
Nematicidal property & Fresh leaves extracts & Sharma and Trivedi, 2002 \\
\hline
\end{tabular}

\section{ORIGIN AND DOMESTICATION}

The center of origin, the center of domestication, and the existence of possible secondary centers of diversity are still open questions for $J$. curcas. Here we want to contribute answers through evidence. The center of origin or primary center of diversity, to begin with, cannot be situated in any other part of the globe than the coastal region of the Gulf of Mexico. There are no records from antiquity of $J$. curcas use and knowledge and its products previous to the Olmecas, in Mexico. In the area of antiquity, it has become clear that the mentioned civilization flourished between 1500 and 3000 years BCE. This is the most ancient $J$. curcas record known. As such, until a record prior to that of the Olmecas is found, J. curcas is originally from Mexico. McVaugh (1945), Wilbur (1954) and Dehgan and Schutzman (1994) defend the Mexican origin, because J. curcas, the most primitive plant species of its type, and related taxa occur there. Basha et al. (2009), analyzing the biochemical and molecular DNA markers of the RAPD, SCAR and ISSR types in 72 accessions of derived $J$. curcas from 13 countries, demonstrated that the Mexican accessions are unique in terms of phorbol ester content (absent or trace presence) and of molecular profile. This rich diversity of the Mexican J. curcas germplasm needs to be incorporated in genetic improvement programs of the species.

The South American origin (Heller, 1996), or perhaps even Brazilian, in this case from the state of Ceará (Martin and Mayeux, 1984), is not very probable, in view of the plant being found in these regions only in association with man; back yards of urban zones and/ or near houses in rural zones as an isolated plant species or living fence. In these regions, there is no record of $J$. curcas reproducing in a wild state in forests or savannas. Basha et al. (2009) also proved that the great biochemical and genetic similarity of the non-Mexican accessions is certainly due to the few introductions in other countries of $J$. curcas originating from Mexico, possibly perpetuated by vegetative propagation, which is the habit of living fence construction. Heller (1996) argues that accessions from Cape Verde were transported to different regions of Asia and Africa by Portuguese navigators. According to Basha and Sujatha (2007), strong similarities between Indian accessions and those from Cape Verde in molecular profiles have been found.

Further, the center of domestication of $J$. curcas cannot be different from Mexico, 
because non-toxic types exist only in that country, probably selected by the Mayans. Harper (1932) described the plants used by the Mayans, and J. curcas is found among them. As already described in the Antiquity item, the exceptional medicinal properties of $J$. curcas made it known to the Olmecas at least 5000 years ago. Certainly, toxicity reduction was a main characteristic sought by the domestication promoted by the Mayans, in order to make its grains and oil edible. Non-toxic $J$. curcas ecotypes do not contain phorbol ester, the main compound responsible for the toxicity of the species, or contain slight traces, with toxins from 0.87 to $3.32 \mathrm{mg} / \mathrm{g}$ (Makkar et al., 1997). Similar observations were reported by Basha et al. (2009), after analyzing 28 Mexican J. curcas ecotypes and comparing them to 44 other derived ecotypes from 12 countries. The character fixation of non-toxicity certainly happened through asexual propagation, which is very easy in J. curcas. Allard (1999), reviewing the history of agriculture developed 13 thousand years ago, evidences the antiquity of the knowledge of asexual propagation. In fact, archaeological records show that vegetative reproduction appeared 13 thousand years ago, being first recorded in Southeast Asian villages (Gorman, 1967).

Surveys carried out in Brazil in the 1980s (CETEC, 1983) in the North of Minas Gerais State, especially including the semi-arid region, detected expressive $J$. curcas concentration. According to CETEC (1983), this region is between latitude $14-20^{\circ}$ and longitude $40-48^{\circ}$ (Figure 1). In the decade of 2000-2010, Andrade et al. (2008) collected accessions in same region and in the entire state of Minas Gerais and, even though they have not found any more such $J$. curcas concentrations, expressive variability has been demonstrated (16 to 45\%) for seed oil content in the north region accessions (Table 2). When the collection of accessions was increased and compared to other accessions collected outside the north region of Minas Gerais State, even from outside the country, the variability for the same trait remained expressive (Table 2). Freitas et al. (2011), analyzing this entire same $J$. curcas collection, found average oil content of $31 \%$ in the seeds and expressive variability for several morphological traits. Although the $t$-test for comparison of means (Table 2) did not show significance, the range for oil content in the accessions of northern region of Minas is very expressive and can allow the selection of superior plants for this trait. $J$. curcas oil was used in lamps for lighting the houses. Therefore, it is reasonable to assume that the populations of that arid and poor region practiced some selection in search of plants with higher oil production.

It is reasonable to suppose that the North Minas Gerais State region may be an important center of diversity of $J$. curcas, or maybe even a secondary center. It is necessary to remember that the deciduousness of $J$. curcas is an adaptive characteristic of the species to resist dry regions, such as the semi-arid region of North Minas Gerais, contributing to increases in its variability in these environments. According to Dehgan and Schutzman (1994), gradual changes in response to dry and/or cold conditions are detected in subtype curcas species. Such evolutionary changes in mosaic are reflected by the great diversity of adaptive types associated with geographical distribution. Still, according to Dehgan and Schutzman (1994), the speciation of Jatropha in the neotropics has been quicker in seasonally dry regions, like the scrubland (grassland-savanna) and caatinga. Furthermore, commercial J. curcas plantations in the semi-arid region of North Minas Gerais is subject to intense incidences of pest attacks (trunk borer and stinkbugs) and diseases (rust, root decay and powdery mildew), corroborating the supposition that the semi-arid area is a possible secondary center of diversity of the species, intimately associated with its natural enemies. 


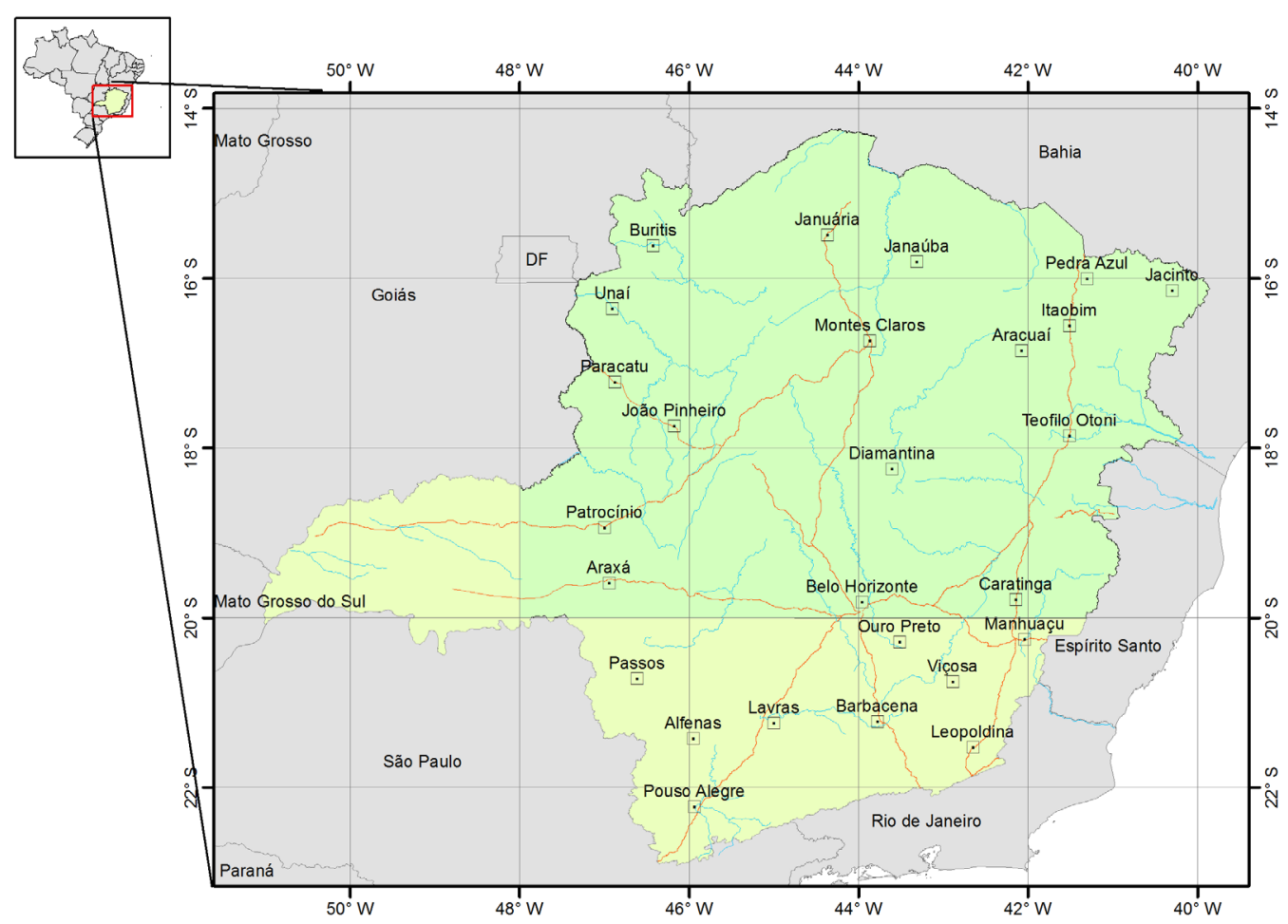

Figure 1. Map of Minas Gerais State, Brazil. CETEC (1983) found high concentrations of Jatropha curcas in the region between $14^{\circ}$ and $20^{\circ}$ latitude and $40^{\circ}$ and $48^{\circ}$ longitude (dark green). Based on analyses of the variability for oil content of accessions collected in that region, when compared with those accessions collected outside, we propose to be the same region a secondary center of diversity of $J$. curcas.

Table 2. Statistical variability for seed oil content of Jatropha curcas accessions collected in the North Minas Gerais State region, in comparison to the accessions collected outside of that region.

\begin{tabular}{lcc}
\hline Statistics & \multicolumn{2}{c}{ Seed oil content $(\%)$} \\
\cline { 2 - 4 } & North of Minas Gerais & Outside North of Minas Gerais \\
\hline No. of accessions & 45 & 29 \\
Minimum & 15.99 & 23.91 \\
Maximum & 45.55 & 38.93 \\
Average & 31.25 & 30.47 \\
Range & 29.56 & 15.02 \\
Variance & 14.67 & 11.92 \\
CV $(\%)$ & 12.25 & 11.33 \\
$t$-test $(\mathrm{P}<0.05)$ & $1.01^{\mathrm{NS}}$ & \\
\hline
\end{tabular}

$\mathrm{CV}=$ coefficient of variation; $\mathrm{NS}=$ nonsignificant.

The knowledge of the centers of diversity of $J$. curcas, in the case of Mexico and semiarid Brazilian regions, is crucial for plant breeding programs for the species. Knowing these centers, breeders can rescue in loco accessions of important genes for improvement, such as pest resistance, disease conditioning, and drought resistance, among others. The knowledge of the centers of domestication of J. curcas, in the case of the Mexican peninsula of the Yucatan, 
can also benefit improvement. Many of the desirable improvement characteristics may already have been selected and fixed in ecotypes. The absence of toxicity, in view of the absence or traces of phorbol ester, is a good example of the contribution of domestication to improvement. The challenge now is to focus future $J$. curcas accessions collections in the above-mentioned regions, increasing the chances of success of plant breeding programs for the species.

\section{ACKNOWLEDGMENTS}

Research supported by FAPEMIG (Fundação de Amparo à Pesquisa do Estado de Minas Gerais), CNPq (Conselho Nacional de Desenvolvimento Científico e Tecnológico), and CAPES (Coordenação de Aperfeiçoamento de Pessoal de Nível Superior).

\section{REFERENCES}

Achten WMJ, Verchot L, Franken YJ and Mathijs E (2008). Jatropha bio-diesel production and use. Biomass Bioenergy 32: 1063-1084.

Adebowale KO and Adedire CO (2006). Chemical composition and insecticidal properties of the underutilized Jatropha curcas seed oil. Afr. J. Biotechnol. 5: 901-906.

Allard RW (1999). History of plant population genetics. Аnпи. Rev. Genet. 33: 1-27.

Andrade VM, Oliveira TS, Sousa LCA, Oliveira GL, et al. (2008). Coleta de Germoplasma de Pinhão Manso (Jatropha curcas L.) nas Regiões do Triângulo, Noroeste e Norte de Minas Gerais. In: $5^{\circ}$ Congresso Brasileiro de Plantas Oleaginosas, Óleos, Gorduras e Biodiesel, UFLA, Varginha, 938-943.

Basha SD and Sujatha M (2007). Inter and intra-population variability of Jatropha curcas (L.) characterized by RAPD and ISSR markers and development of population-specific SCAR markers. Euphytica 156: 375-386.

Basha SD, Franis G, Makkar HPS, Becker K, et al. (2009). A comparative study of biochemical traits and molecular markers for assessment of genetic relationships between Jatropha curcas L. germplasm from different countries. Plant Sci. 176: 812-823.

CETEC (1983). Produção de Combustíveis Líquidos a Partir de Óleos Vegetais. 1. Estudo das Oleaginosas Nativas de Minas Gerais. CETEC, Belo Horizonte.

Coe FG (2008). Ethnomedicine of the Rama of Southeastern Nicaragua. J. Ethnobiol. 28: 1-38.

Dahmer N, Schifino-Wittmann MT and Dias LAS (2009). Chromosome numbers of Jatropha curcas L.: an important agrofuel plant. Crop Breed. Appl. Biotechnol. 9: 386-389.

Dehgan B and Schutzman B (1994). Contributions toward a monograph of neotropical Jatropha: phenetic and phylogenetic analyses. Ann. Missouri Bot. Garden 81: 349-367.

Dias LAS (2011). Biofuel plant species and the contribution of genetic improvement. Crop Breed. Appl. Biotechnol. S1: 16-26.

Dias LAS, Leme LP, Laviola BG, Pallini A, et al. (2007). Cultivo de Pinhão Manso (Jatropha curcas L.) para Produção de Óleo Combustível. UFV, Viçosa.

Dias LAS, Muller M and Freire E (2008). Potencial do Uso de Oleaginosas Arbóreas em Sistemas Silvipastoris. In: Sistemas Agrossilvipastoris na América do Sul: Desafios e Potencialidades (Fernandes EM, Paciullo DSC, Castro CRT and Muller MD, eds.). Embrapa Gado de Leite, Juiz de Fora, 283-314.

Emmart EW (1961). Notes on Aztec dye plants: Indians of prehistoric Mexico skilled in use of natural colorings. Plants Gardens 20: 83-85.

Fairless D (2007). Biofuel: the little shrub that could-maybe. Nature 449: 652-655.

Foidl N, Foidl G, Sanchez M, Mittelbach M, et al. (1996). Jatropha curcas L. as a source for the production of biofuel in Nicaragua. Biores. Technol. 58: 77-82.

Freitas RG, Missio RF, Matos FS, Resende MD, et al. (2011). Genetic evaluation of Jatropha curcas: an important oilseed for biodiesel production. Genet. Mol. Res. 10: 1490-1498.

Gexsi LLP (2008). Global Market Study on Jatropha. Project Inventory: Latin America. WWF, London/Berlin.

Ghosh A, Patolia JS, Chaudhary DR and Chikara J (2007). Response of Jatropha curcas Under Different Spacing to Jatropha De-oiled Cake. Available at [www.fact-foundation.com/media_en/Jatropha_presscake_as_fertilizer]. Accessed June 16, 2012. 
Gorman C (1967). A Priori Models and Thai Prehistory: A Reconsideration of the Beginnings of Agriculture in Southeastern Asia. In: Origins of Agriculture (Reed CA, ed.). The Hague, Mouton, 351-355.

Gübitz GM, Mittelbach M and Trabi M (1999). Exploitation of the tropical oil seed plant Jatropha curcas L. Biores. Technol. 67: 73-82.

Harper RM (1932). Useful plants of Yucatan. J. Torrey Bot. Soc. 59: 279-288.

Haude ME (1998). Identification of colorants on maps from the early colonial period of New Spain (Mexico). J. Am. Inst. Conserv. 37: 240-270.

Heller J (1996). Physic Nut (Jatropha curcas L.): Promoting the Conservation and Use of Underutilized and Neglected Crops. Institute of Plant Genetics and Crop Plant Research, Rome.

Jongschaap REE, Corré WJ, Bindraban PS and Brandenburg WA (2007). Claims and Facts on Jatropha curcas L. Plant Resource International, Wageningen.

Laviola BG and Dias LAS (2008). Teor e acúmulo de nutrientes em folhas e frutos de pinhão-manso. Rev. Bras. Ciênc. Solo 32: 1969-1975.

Leonti M, Sticher O and Heinrich M (2003). Antiquity of medicinal plant usage in two Macro-Mayan ethnic groups (Mexico). J. Ethnopharmacol. 88: 119-124.

Makkar HPS, Becker K, Sporer F and Wink M (1997). Studies on nutritive potential and toxic constituents of different provenances of Jatropha curcas. J. Agric. Food Chem. 45: 3152-3157.

Martin G and Mayeux A (1984). Reflections on oil crops as sources of energy. II. The physic nut (Jatropha curcas L.) a possible source of fuel. Oléagineux 39: 283-287.

McVaugh R (1945). The genus Jatropha in America: principal intergeneric groups. Bull. Torrey Bot. Club 72: 271-294.

Nogueira LAH (2004). Perspectivas de un Programa de Biocombustibles en América Central. CEPAL/GTZ, México.

Openshaw K (2000). A review of Jatropha curcas: an oil plant of unfulfilled promise. Biomass Bioenergy 19: 1-15.

Pramanik K (2003). Properties and use of Jatropha curcas oil and diesel fuel blends in compression ignition engine. Renew. Energ. 28: 239-248.

Rug M, Sporer F, Wink M, Liu SY, et al. (1997). Molluscicidal Properties of J. curcas Against Vector Snails of the Human Parasites Schistosoma mansoni and S. japonicum. In: Biofuels and Industrial Products from Jatropha curcas - Proceedings from the Symposium 'Jatropha 97' (Gübitz GM, Mittelbach M and Trabi M, eds.). Austrian Ministry of Foreign Affairs and Sucher \& Holzer Graz, Austria, 227-232.

Sharma N and Trivedi PC (2002). Screening of leaf extracts of some plants for their nematicidal and fungicidal properties against Meloidogyne incognita and Fusarium oxysporum. Asian J. Exp. Sci. 16: 21-28.

Standley PC (1967). Trees and Shrubs of Mexico. Smithsonian Institution, Washington.

Visser EM, Oliveira Filho D, Martins MA and Steward BL (2011). Bioethanol production potential from Brazilian biodiesel co-products. Biomass Bioenergy 35: 489-494.

Wallert A (1997). The Analysis of Dyestuffs on Historical Textiles from Mexico. In: The Unbroken Thread: Conserving the Textile Traditions of Oaxaca (Kathryn Klein, ed.). J. Paul Getty Trust, Los Angeles, 57-85.

Wilbur RL (1954). A synopsis of Jatropha, subsection Eucurcas, with the description of two new species from Mexico. J. Elisha Mitchell Sci. Soc. 70: 92-101.

Zahawi RA (2005). Establishment and growth of living fence species: an overlooked tool for the restoration of degraded areas in the tropics. Restoration Ecol. 13: 92-102. 